\title{
Mortality- and Health-Related Factors in a Community-Dwelling of Oldest-Older Adults at the Age of 90: A 10-Year Follow-Up Study
}

\author{
Yoshiaki Nomura ${ }^{1, *}$,, Mieko Shimada ${ }^{2}$, Erika Kakuta ${ }^{3}$, Ayako Okada ${ }^{1}$, Ryoko Otsuka ${ }^{1}$, \\ Yasuko Tomizawa ${ }^{4}$, Chieko Taguchi ${ }^{5}$, Kazumune Arikawa ${ }^{5}$, Hideki Daikoku ${ }^{6}$, Tamotsu Sato ${ }^{6}$ \\ and Nobuhiro Hanada ${ }^{1}$ (D) \\ 1 Department of Translational Research, School of Dental Medicine, Tsurumi University, \\ Yokohama 230-8501, Japan; okada-a@tsurumi-u.ac.jp (A.O.); otsuka-ryoko@tsurumi-u.ac.jp (R.O.); \\ hanada-n@tsurumi-u.ac.jp (N.H.) \\ 2 Department of Dental Hygiene, Chiba Prefectural University of Health Sciences, Chiba 261-0014, Japan; \\ mieko.shimada@cpuhs.ac.jp \\ 3 Department of Oral Bacteriology, School of Dental Medicine, Tsurumi University, Yokohama 230-8501, Japan; \\ kakuta-erika@tsurumi-u.ac.jp \\ 4 Department of Cardiovascular Surgery, Tokyo Women's Medical University, Tokyo 162-8666, Japan; \\ tomizawa.yasuko@twmu.ac.jp \\ 5 Department of Preventive and Public Oral Health, School of Dentistry at Matsudo, Nihon University, \\ Matsudo 470-2101, Japan; taguchi.chieko@nihon-u.ac.jp (C.T.); arikawa.kazumune@nihon-u.ac.jp (K.A.) \\ 6 Iwate Dental Association, Morioka 020-0045, Japan; dai-koku@nifty.com (H.D.); \\ tamosato-dent@k-2inc.jp (T.S.) \\ * Correspondence: nomura-y@tsurumi-u.ac.jp; Tel.: +81-45-580-8462
}

Received: 13 November 2020; Accepted: 17 December 2020; Published: 21 December 2020

\begin{abstract}
Mortality is obviously intended for epidemiological studies of community-dwelling older adults. There are several health-related factors associated with nutritional status and mortality. The aim of this study was to elucidate the risk factor for mortality in community-dwelling oldest-older adults at the age of 90 and clarify the structure of health-related factors associated with mortality. A 10-year follow-up study was performed for 93 subjects at the age of 90 . The mean and median of their survival days were 2373 and 2581 days for women, and 1694 and 1793 days for men. By Cox's proportional hazards model, health-related factors associated with mortality were self-assessed for chewing ability, activities of daily living (ADLs), serum albumin, total cholesterol, serum creatinine, and gripping power for women but not for men. These factors interacted with each other, and the association of these factors was different in women and men. Self-assessed chewing ability was a powerful risk factor for mortality in women at the age of 90 . It acted independently from nutritional status. For older adults, addressing healthy food choices together with improved oral functions is useful. However, risk factors for mortality may depend on the life stage of subjects. To investigate the risk factor for the mortality, the life course approach is necessary.
\end{abstract}

Keywords: mortality; self-assessed chewing ability; serum albumin; ADL; physical performance

\section{Introduction}

Mortality is obviously intended for epidemiological studies of community-dwelling older adults. Many health-related factors associated with mortality interact with each other [1-6]. Therefore, health-related factors associated with mortality comprise a complex structure.

Sufficient nutritional status is essential for maintaining health in older adults. A positive ageing process depends on adequate nutritional status [7]. Poor nutritional status leads to adverse health 
outcomes [8,9]. It results in functional decline and frailty $[10,11]$ and has been suggested to be a risk for mortality $[8,9]$.

Oral health status has a recondite impact on nutritional status. Food consistency and food choice have been adapted to oral status [12]. The association between impaired masticatory function and deficient dietary intake has been suggested $[13,14]$. Suboptimal nutritional status after impaired oral function can result in chronic diseases [15]. In addition, impaired oral function and dysphagia increases the risk of aspiration pneumonia and choking $[16,17]$. Several studies have suggested that self-assessed chewing ability or mastication deficiency is a risk for mortality [18-21]. However, for addressing oral health and nutrition, well-designed studies are still not enough [22].

Nutritional status and diet quality effect the physical performance and activities of daily living (ADLs) $[9,23,24]$, as well as oral health-related to physical performance and ADLs [25-27]. Therefore, health-related factors can interact with each other and impact mortality.

Regarding community-dwelling older adults, evidence has been accumulated for the numerous risk factors associated with mortality. Studies have found that specific health-related factors are regarded as risks after adjustment for common risk factors. An investigation was performed within specific health-related factors, including nutrition [28,29], oral health [30-38], and physical performance [39-45]. In addition to this risk evaluation, a comprehensive assessment for the risk factors for mortality is necessary for planning health promotion for older adults [46,47], decision of priority of intervention [48-50], and health-related political decision-making.

In 1997, the Japanese Ministry of Labor and Health directed and supported a survey of 80-year-old people residing in four areas of Japan. The aims of the survey were to investigate the relationship between oral health and systemic health in 80-year-old adults. Iwate Prefecture, located in the northern region of Japan, was one of the areas participating in this survey. The survey items were common to the baseline study. Then, four areas were independently carried out in the follow-up study. Iwate Prefecture conducted the 5-year follow-up (85 years of age), 10-year follow-up (90 years of age), and 20-year follow-up (100 years old). Previous reports had shown the importance of chewing ability for mortality [51,52]. In this study, all the data in the 10-year follow-up study (90 years of age) were analyzed, including chewing ability.

We assessed the association between mortality and health status via blood tests, including reflection of nutritional status, oral health status via self-assessed chewing ability, physical performance, and activities of daily living (ADLs). The magnitude of health-related factors pertinent to mortality were investigated. In addition, the correlation between mortality and these health-related factors were summarized.

The aim of this study was to elucidate the risk factor for mortality in community-dwelling oldest-older adults at the age of 90 and clarify the structure of health-related factors associated with mortality.

\section{Materials and Methods}

\subsection{Setting}

A 20-year follow-up survey was conducted on 80-year-old subjects living in 10 districts managed by one health center in Iwate Prefecture in northern Japan. For 20 years, heath examinations were conducted three times in 1997 for the 80-year-old subjects, in 2002 at the age of 85, and 2007 at the age of 90 . Oral examination, physical performance measures, blood tests and questionnaire surveys were conducted as health examinations. Other than these three-times survey, no health examinations were conducted. In this study, data of subjects at the age of 90 were analyzed in a 10-year follow-up survey (2007-2017). 


\subsection{Study Population and Follow-Ups}

In Japan, the Family Register Act obligated all Japanese citizens to register their birth, death, still birth, marriage, and divorce to municipality offices as residential registration.

In 2007, a complete count survey using cluster sampling based on residential registration in 10 districts was performed for all subjects over the age of 90 (i.e., born in 1917). Public health nurses visited the homes of 90-year-old individuals in order to recommend who should participate in the survey. A total of 100 subjects completed the survey. In October 2017, survival and dates of death were surveyed by the census register of 10 district [51-53].

\subsection{Oral Examination}

Oral examinations were carried out by a dentist. Dentists counted the number of remaining teeth and their locations and denture use was recorded.

\subsection{Physical Performance Measures}

To test normal walking speed, participants were asked to walk once on a straight $11 \mathrm{~m}$ walkaway on a flat floor at a normal speed. Walking speed was measured at a distance of $5 \mathrm{~m}$ between markers located 3 and $8 \mathrm{~m}$ from the start of the walkaway [54].

A Smedley type hand dynamometer (Yagami Co, Tokyo, Japan) was used to measure grip strength of both hands. A higher value of grip strength was employed [55].

One-leg standing time was an indicator of static balance. In the one-legged standing time test, we asked participants to stand on their preferred leg with their eyes open and hands down alongside their trunk and to look straight ahead at a dot $1 \mathrm{~m}$ in front of them. The duration of standing time was measured for up to $60 \mathrm{~s}$, and the higher value from 2 trials was used in the analysis [54-56]. The stepping rate at sitting position was measured with a stepping rate counter. Participants were instructed to step on each leg as fast as possible for $10 \mathrm{~s}$. The number of steps of both feet was totaled as the score [55].

\subsection{Blood Tests and Blood Pressure}

The health status of the subjects was evaluated using blood tests. Blood samples were collected before physical performance tests and oral examinations. Samples were kept on ice until the transport to a medical examination company. The inspected items were aspartate transaminase (AST), alanine aminotransferase (ALT), $\gamma$-glutamic pyruvic transaminase $(\gamma$-GTP), total protein, albumin, total cholesterol, triglyceride, high-density lipoprotein (HDL), low-density lipoprotein (LDL), creatinine, calcium, phosphate, glucose, hemoglobin A1c (HbA1c), IgG, IgA, and IgM. Blood pressure was measured by physician. Systolic pressure and diastolic pressure were recorded.

\subsection{Questionnaire}

\subsubsection{Self-Assessed Chewing Ability}

Self-assessed chewing ability was investigated using the simple dichotomous choice: "Can you chew the following 15 foods?" The response solicited either a yes or no answer [20,52,53].

\subsubsection{Activities of Daily Living (ADLs)}

Instrumental activity of daily living was evaluated using the Tokyo Metropolitan Institute of Gerontology (TMIG) index of competence [57]. Three subscales of the TMIG index were self-maintenance, intellectual activity, and social role. These subscales consisted of 5,4 , and 4 items. If subjects answered yes, it was counted as one point. A low point for self-maintenance ( $\leq 4$ points), for intellectual activity ( $\leq 2$ points), and for social role ( $\leq 2$ points) were regarded as functional decline $[58,59]$. 


\subsection{Statistical Analysis}

\subsubsection{Item Response Theory (IRT)}

A three-parameter logistic model was applied for the summary score of self-assessed chewing ability. Item response curves and item information curves were presented for 15 types of food [60-64]. $R$ ver3.50 with the LTR and irtoys packages was used for IRT analysis.

\subsubsection{Survival Analysis}

To calculate the hazard ratios, the Cox proportional hazards model was used. Survival rates were calculated using the Kaplan-Meier analysis. Differences in survival curves were evaluated using the log-rank test, the Breslow test, and the Tarone-Ware test [52,53]. These analyses were carried out using SPSS Statistics ver24.0 (IBM, Tokyo, Japan)

\subsubsection{Structural Equation Modeling (SEM) and Path Analysis}

Structural equation modeling (SEM) was performed for the subscales of the TMIG index [52]. For factor-associated mortality, path analysis was performed [51]. The root mean square error of approximation (RMSEA) was used for the goodness of fit index $[65,66]$. SEM and path analysis were carried out using AMOS ver24.0 (IBM, Tokyo, Japan).

\subsection{Ethics Approval}

For the baseline survey, informed written consent was obtained from participants. This study was approved by the Ethics Committee of Tsurumi University School of Dental Medicine (Approval Number: 1515).

\section{Results}

\subsection{Characteristics of the Subjects}

The subjects that participated in this study were all born in 1917 and were 90 or 89 years old when the survey was conducted (September to October 2007). The health status evaluation of the subjects at the age of 90 was only one part of this survey. Among the 100 subjects who participated in this 2007 survey, 92 subjects could follow-up their health status after 10 years. The study population consisted of 58 men and 34 women. The mean and median of their survival days were 2373 and 2581 days for women, and 1694 and 1793 days for men. Their 95\% confidential intervals (95\% CI) were 2051 to 2696 days for the mean of women, 1857 to 3305 days for the median of women, 1365 to 2023 days for the mean of men, and 1079 to 2507 days for the median of men, respectively. Descriptive statistics of the all the variables analyzed in this study are shown Table S1.

\subsection{Effect of Self-Assessed Chewing Ability for Mortality}

\subsubsection{Analysis of Self-Assessed Chewing Ability Using IRT}

Self-assessed chewing ability was analyzed via a three-parameter logistic model based on IRT. The item response curves and item information curves were shown in Figure 1. Among the 15 types of different food, steamed rice, Konnyaku jelly, yellow pickled radish, and dried cuttlefish had steep item response curves and high item information. The results of the three-parameter logistic model are shown in Table S2. The weighted sum of each item was calculated for the following analysis. 
(A)
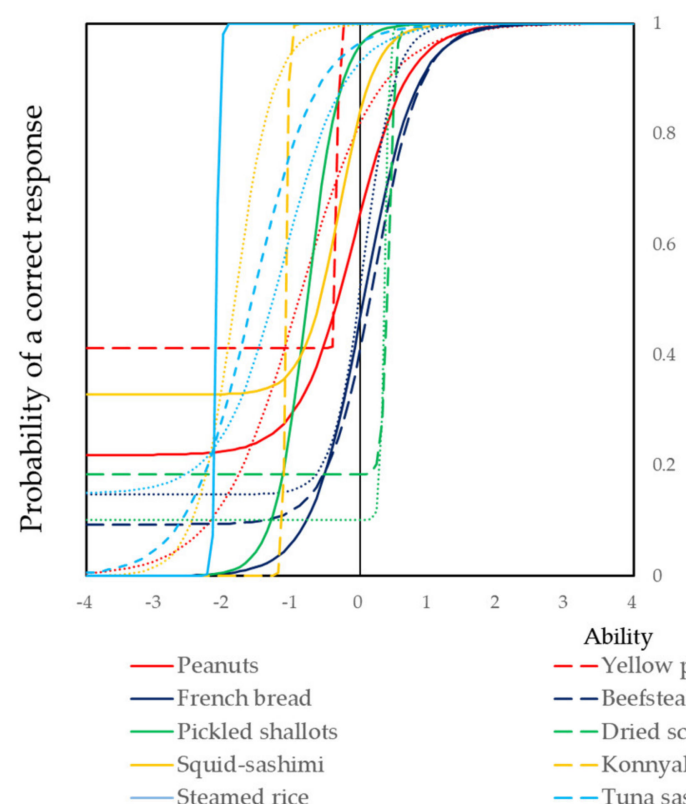

(B)

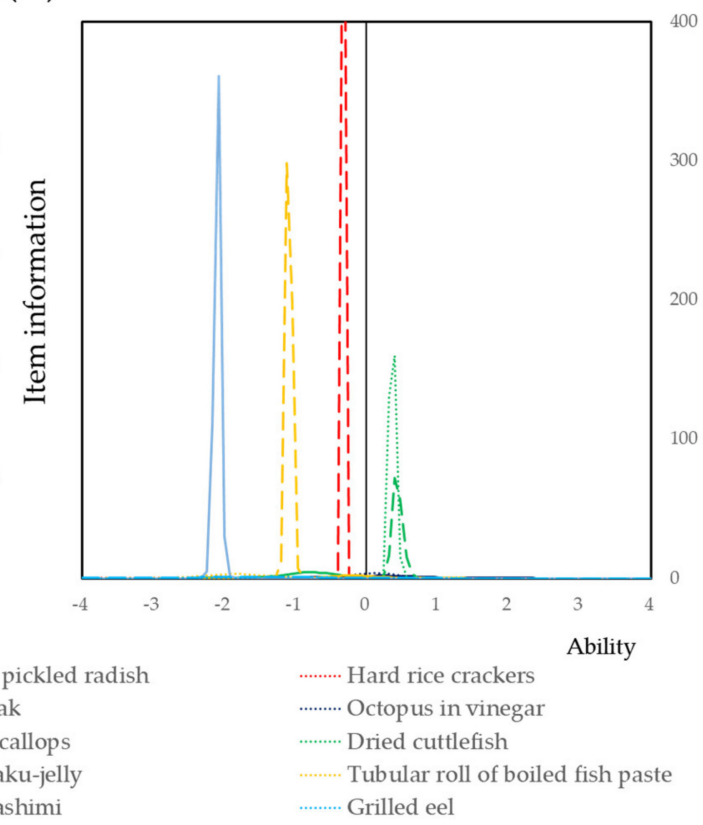

Figure 1. Item response curve (A) and item information curves (B) for 15 types of different food. Subjects participated in this study answered chewable "Yes" or "No" for different foods. The item response curves and item information curves were located in a backward direction to indicate easy to chew food. The curves with a forward direction indicate difficult to chew food.

\subsubsection{The Effect of Self-Assessed Chewing Ability on Mortality}

The effect of self-assessed chewing ability on mortality was analyzed using Cox's proportional hazard model, which was calculated via IRT. The results are shown in Table 1. Self-assessed chewing ability was statistically significant for women, but not significant for men. The number of remaining teeth and denture use were not significant. To describe the survival curves for the Kaplan-Meyer analysis, the ability of self-assessed chewing ability was dichotomized with the value's median. The values were labelled as having sufficient or not sufficient chewing ability. The survival curves were illustrated in Figure 2. For women, the difference was statistically significant using the log-rank test, the Breslow test, and the Tarone-Ware test $(p<0.001, p=0.001$, and $p<0.001$ for woman, respectively). However, it was not significant for men ( $p=0.751 . p=0.828$, and $p=0.992$, respectively). Among the 15 types of food, statistical significance for the mortality of women was obtained for two foods: dried scallops and Konnyaku jelly. The survival curves for these two foods are shown in Figure S1. The results from Cox's proportional hazard model analysis for the 15 foods are shown in Table S3.

Table 1. Results of Cox's proportional hazard model analysis for self-assessed chewing ability.

\begin{tabular}{cccccc}
\hline & \multicolumn{2}{c}{ Women } & \multicolumn{2}{c}{ Men } \\
\cline { 2 - 6 } & & Hazard Ratio (95\% CI) & $p$-Value & Hazard Ratio (95\% CI) & $p$-Value \\
\hline \multirow{2}{*}{$\begin{array}{c}\text { Self-assessed } \\
\text { Chewing ability }\end{array}$} & Continuous & $1.692(1.050-2.725)$ & 0.031 & $0.920(0.641-1.320)$ & 0.651 \\
\cline { 2 - 6 } & Dichotomous & $6.742(2.09-21.751)$ & 0.001 & $1.157(0.469-2.851)$ & 0.751 \\
\hline Number of remaining teeth & $1.050(0.952-1.158)$ & 0.332 & $1.013(0.961-1.066)$ & 0.638 \\
\hline \multicolumn{2}{c}{ Denture use (Use/No use) } & $2.511(0.591-10.674)$ & 0.213 & $1.523(0.521-4.457)$ & 0.442 \\
\hline
\end{tabular}




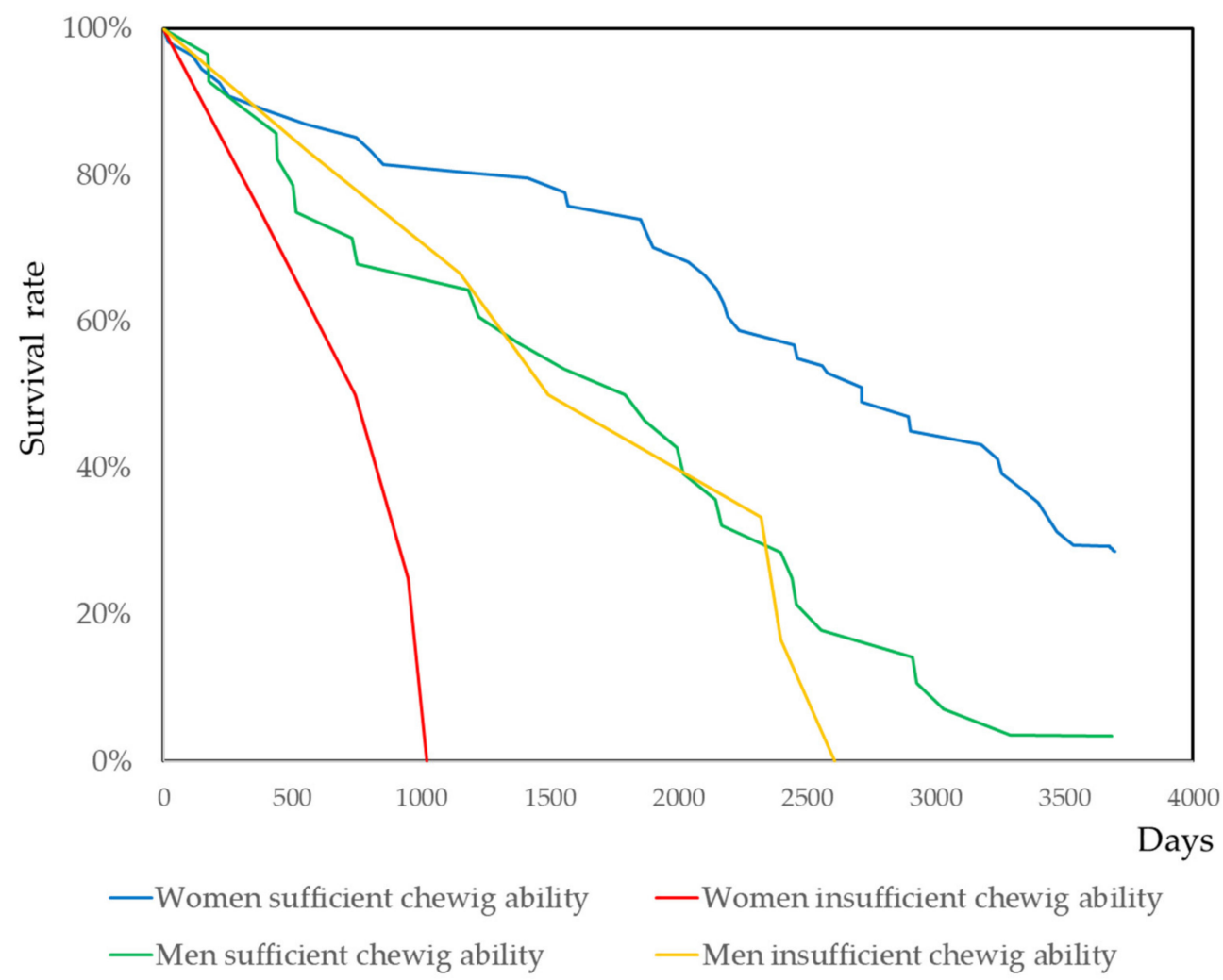

Figure 2. Survival curves by self-chewing ability. Sufficiency of chewing ability was determined by the above or less of the median value, the cut off was -1 of the ability shown in Figure 1 . Statistical significance was evaluated using the log-rank test, the Breslow tests, and the Tarone-Ware test $(p<0.001, p=0.001$, and $p<0.001$ for woman; $p=0.751$. $p=0.828$, and $p=0.992$ for men, respectively).

\subsection{Effect of Health Status by Blood Tests for Mortality}

In this study, health status was evaluated via blood tests and blood pressure. For each blood test, Cox's proportional hazard model was applied (Table 2). For women, albumin, total cholesterol, and creatine were statistically significant. However, there was no significant test for men. For self-assessed chewing ability and ADLs, the adjusted hazard ratio was calculated using these three blood tests. The results were shown in Table S4. After a serum albumin adjustment, self-assessed chewing ability was statistically significant for women. After adjusting for total cholesterol, ADL was significant for women.

Table 2. Results of Cox's proportional hazard model for health status evaluated using blood tests and blood pressure.

\begin{tabular}{cccccc}
\hline & & \multicolumn{2}{c}{ Women } & & Men \\
\cline { 3 - 6 } & & Hazard Ratio (95\% CI) & $p$-Value & Hazard Ratio (95\% CI) & $p$-Value \\
\cline { 3 - 6 } & AST (U/L) & $1.036(0.985-1.090)$ & 0.173 & $1.007(0.984-1.030)$ & 0.571 \\
Hepatic & ALT (U/L) & $1.030(0.970-1.093)$ & 0.336 & $0.980(0.924-1.039)$ & 0.497 \\
function & $\gamma$-GTP (U/L) & $1.023(0.985-1.061)$ & 0.235 & $1.005(0.982-1.028)$ & 0.665 \\
& Total protein (g/dL) & $1.252(0.506-3.106)$ & 0.627 & $2.725(0.953-7.752)$ & 0.061 \\
& Albumin (g/dL) & $3.333(1.09-10.101)$ & 0.034 & $2.070(0.475-9.009)$ & 0.332 \\
\hline \multirow{2}{*}{ Lipid } & Total cholesterol (mg/dL) & $1.073(1.003-1.032)$ & 0.021 & $1.007(0.992-1.022)$ & 0.386 \\
metabolism & Try glyceride (mg/dL) & $0.999(0.994-1.004)$ & 0.735 & $0.999(0.990-1.007)$ & 0.807 \\
& HDL (mg/dL) & $1.026(0.998-1.054)$ & 0.073 & $0.991(0.963-1.020)$ & 0.555 \\
\cline { 3 - 6 } Renal & LDL (mg/dL) & $1.013(0.997-1.029)$ & 0.108 & $1.014(0.996-1.032)$ & 0.130 \\
\hline function & Creatinine (mg/dL) & $12.770(1.627-100.211)$ & 0.015 & $1.372(0.364-5.165)$ & 0.640 \\
\hline
\end{tabular}


Table 2. Cont.

\begin{tabular}{|c|c|c|c|c|c|}
\hline & & \multicolumn{2}{|l|}{ Women } & \multicolumn{2}{|l|}{ Men } \\
\hline & & Hazard Ratio (95\% CI) & $p$-Value & Hazard Ratio (95\% CI) & $p$-Value \\
\hline \multirow{3}{*}{$\begin{array}{c}\text { Bone } \\
\text { metabolism }\end{array}$} & Calcium (mg/dL) & $1.057(0.503-2.208)$ & 0.883 & $2.096(0.541-8.130)$ & 0.284 \\
\hline & Phosphate (mg/dL) & $1.474(0.695-3.128)$ & 0.312 & $1.314(0.620-2.785)$ & 0.475 \\
\hline & Calcium/Phosphate & $1.471(0.657-3.290)$ & 0.348 & $1.412(0.723-2.762)$ & 0.312 \\
\hline \multirow{2}{*}{$\begin{array}{l}\text { Carbohydrate } \\
\text { metabolism }\end{array}$} & Glucose (mg/dL) & $1.002(0.995-1.008)$ & 0.654 & $1.004(0.997-1.011)$ & 0.276 \\
\hline & HbA1c $(\%)$ & $1.165(0.692-1.961)$ & 0.565 & $1.023(0.712-1.469)$ & 0.903 \\
\hline \multirow{3}{*}{$\begin{array}{l}\text { Immune } \\
\text { function }\end{array}$} & $\operatorname{IgG}(\mathrm{mg} / \mathrm{dL})$ & $1.000(0.999-1.001)$ & 0.834 & $0.999(0.998-1.000)$ & 0.231 \\
\hline & $\operatorname{IgA}(\mathrm{mg} / \mathrm{dL})$ & $1.001(0.998-1.003)$ & 0.705 & $0.996(0.993-0.999)$ & 0.017 \\
\hline & $\operatorname{IgM}(\mathrm{mg} / \mathrm{dL})$ & $0.993(0.984-1.002)$ & 0.108 & 1.003 (0.993-1.012) & 0.601 \\
\hline \multirow{2}{*}{$\begin{array}{c}\text { Blood } \\
\text { pressure }\end{array}$} & $\begin{array}{l}\text { Systolic pressure } \\
(\mathrm{mmHg})\end{array}$ & $0.990(0.971-1.010)$ & 0.330 & $0.993(0.972-1.014)$ & 0.514 \\
\hline & $\begin{array}{c}\text { Diastolic pressure } \\
(\mathrm{mmHg})\end{array}$ & $0.998(0.974-1.024)$ & 0.901 & $1.008(0.977-1.040)$ & 0.611 \\
\hline
\end{tabular}

AST: aspartate transaminase, ALT: alanine aminotransferase, $\gamma$-GTP: $\gamma$-glutamic pyruvic transaminase, HDL: high-density lipoprotein, LDL: low-density lipoprotein, HbA1c: hemoglobin A1c.

\subsection{Effect of ADLs for Mortality}

\subsubsection{Structure of TMIG Index}

The TMIG index consisted of three subscales. The structure of the TMIG index was analyzed using structural equation modeling (SEM). The result is shown in Figure 3. The subscales of "self-management", "social role", and "intellectual activity" were correlated with each other.

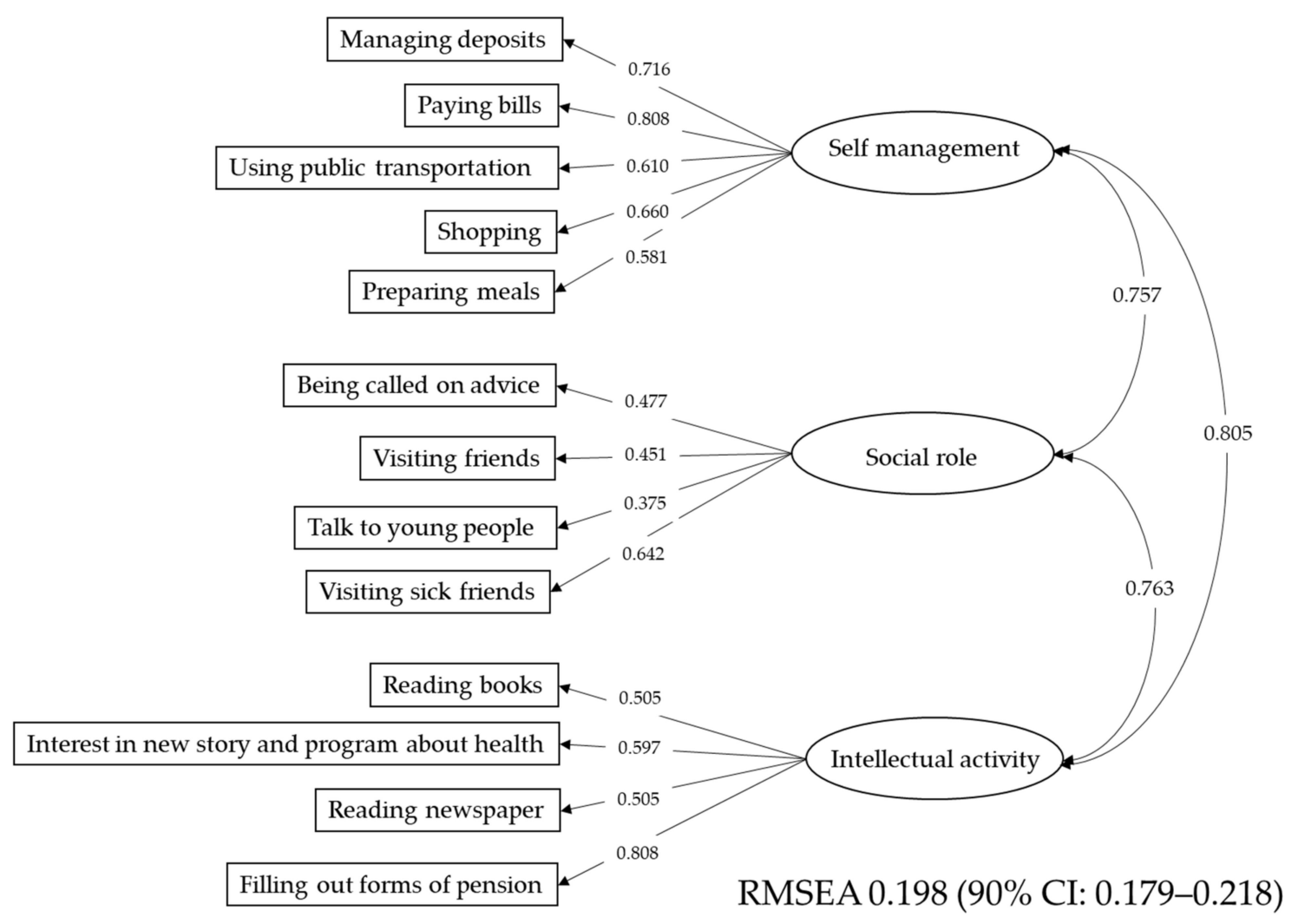

Figure 3. Structure of activities of daily living (ADLs). ADLs were evaluated using the TMIG index. The TMIG index consisted of 3 subscales: "self-management", "social role", and "intellectual activity". These subscales were highly correlated with each other. TMIG index: Tokyo Metropolitan Institute of Gerontology Index, REMSEA: root mean square error of approximation. 


\subsubsection{Effect of ADLs on Mortality}

Similarly, the effect of ADLs on mortality was analyzed using Cox's proportional hazard model and the Kaplan-Meyer analysis. The results of Cox's proportional hazard model are shown in Table 3. As there is no cutoff for the total TMIG index score, the three subscales have cutoffs. Subscales were treated as a dichotomous variable. In addition to total TMIG index scores, the "self-management" subscale was statistically significant for both women and men. Survival curves are illustrated in Figure 4. The survival curves of "intellectual activity" and "social role" are shown in Figure S1.

Table 3. Results of Cox's proportional hazard model analysis for the TMIG index.

\begin{tabular}{ccccc}
\hline & \multicolumn{2}{c}{ Women } & \multicolumn{2}{c}{ Men } \\
\cline { 2 - 5 } & Hazard Ratio (95\% CI) & $p$-Value & Hazard Ratio (95\% CI) & $p$-Value \\
\hline TMIG Index & $1.124(1.020-1.240)$ & 0.019 & $1.023(0.921-1.136)$ & 0.670 \\
\hline $\begin{array}{c}\text { Self-management } \\
(\leq 4 \text { points/>5 points })\end{array}$ & $2.119(1.003-4.643)$ & 0.048 & $5.882(1.822-18.878)$ & 0.003 \\
\hline $\begin{array}{c}\text { Intellectual activity } \\
(\leq 2 \text { points/>3 points })\end{array}$ & $1.484(0.801-1.249)$ & 0.210 & $1.304(0.451-3.774)$ & 0.624 \\
\hline $\begin{array}{c}\text { Social role } \\
(\leq 2 \text { points }>\text { 3 points })\end{array}$ & $1.669(0.900-3.096)$ & 0.104 & $1.107(0.351-2.489)$ & 0.806 \\
\hline
\end{tabular}

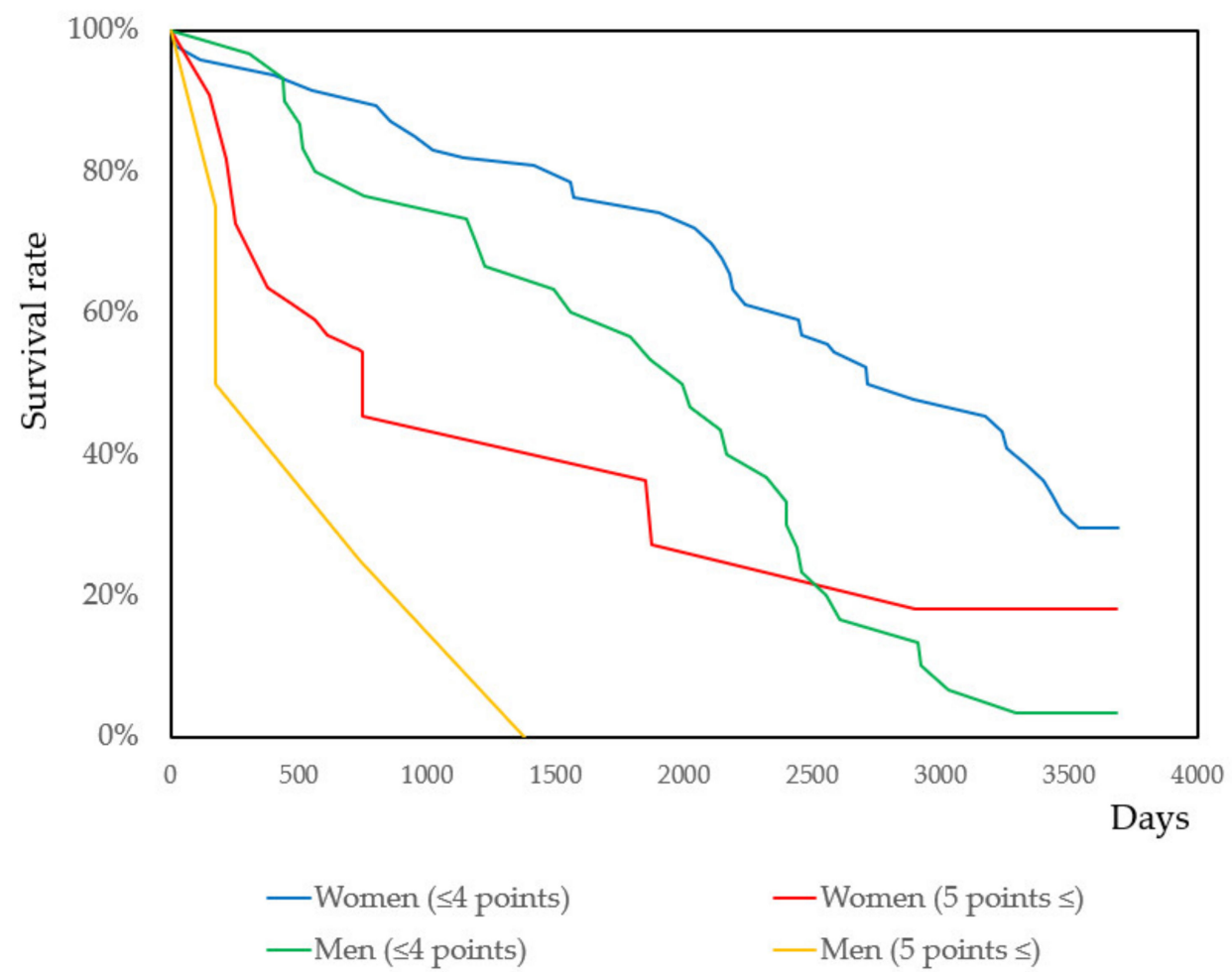

Figure 4. Survival curves by self-management as ADL. The subjects who participated in this study were classified as "self-management", which was one of the subscales in the TMIG index. Statistical significance was evaluated using the log-rank test, the Breslow tests, and the Tarone-Ware test ( $p=0.043$, $p=0.008$, and $p<0.014$ for woman; $p=0.001$. $p=0.001$, and $p=0.001$ for men, respectively).

\subsection{The Effect of Physical Fitness for Mortality}

Hazed ratios for physical fitness were analyzed using Cox's proportional hazard model. The results are shown in Table 4. Only female hand grip strength had statistical significance. 
Table 4. Results of Cox's proportional hazard model for physical performance.

\begin{tabular}{cccccc}
\hline & & \multicolumn{2}{c}{ Women } & \multicolumn{2}{c}{ Men } \\
\cline { 2 - 5 } & & Hazard Ratio (95\% CI) & $p$-Value & Hazard Ratio (95\% CI) & $p$-Value \\
\hline \multirow{2}{*}{$\begin{array}{c}\text { One-legged standing time with } \\
\text { eyes open (min) }\end{array}$} & $0.999(0.916-1.089)$ & 0.977 & $1.034(0.945-1.131)$ & 0.461 \\
\hline \multirow{5}{*}{ Stepping } & $\begin{array}{c}\text { Mean of right and } \\
\text { left (steps/10s) }\end{array}$ & $1.019(0.982-1.057)$ & 0.323 & $1.027(0.974-1.083)$ & 0.326 \\
\cline { 2 - 6 } & $\begin{array}{c}\text { Maximum of right } \\
\text { and left (steps/10s) }\end{array}$ & $1.026(0.989-1.064)$ & 0.174 & $1.034(0.979-1.093)$ & 0.230 \\
\cline { 2 - 6 } & Both legs (steps/10s) & $1.009(0.991-1.028)$ & 0.323 & $1.013(0.987-1.041)$ & 0.326 \\
\hline \multirow{3}{*}{5 m walk } & Number of steps & $1.012(0.988-1.037)$ & 0.315 & $1.035(0.929-1.153)$ & 0.530 \\
\cline { 2 - 6 } & Time (s) & $1.042(0.992-1.094)$ & 0.101 & $1.056(0.917-1.215)$ & 0.451 \\
\cline { 2 - 6 } & Distance $(\mathrm{m})$ & $0.815(0.414-1.606)$ & 0.555 & $0.945(0.457-1.952)$ & 0.878 \\
\hline
\end{tabular}

\subsection{Overview of the Correlation between Health-Related Factors and Mortality}

Based on the results described above, a path diagram was constructed (Figure 5). The red numbers indicate that the coefficient of women, whereas blue numbers indicate the coefficient of men. The coefficients were different between women and men. The effect of self-assessed chewing ability on serum albumin was higher in men and its direct effect on mortality was higher in women. Gripping power effected ADLs both in men and women. The effect of ADLs on mortality was higher in women. The effects of serum creatinine and total cholesterol were higher in women. In contrast, the effect of serum albumin on mortality was higher in men.

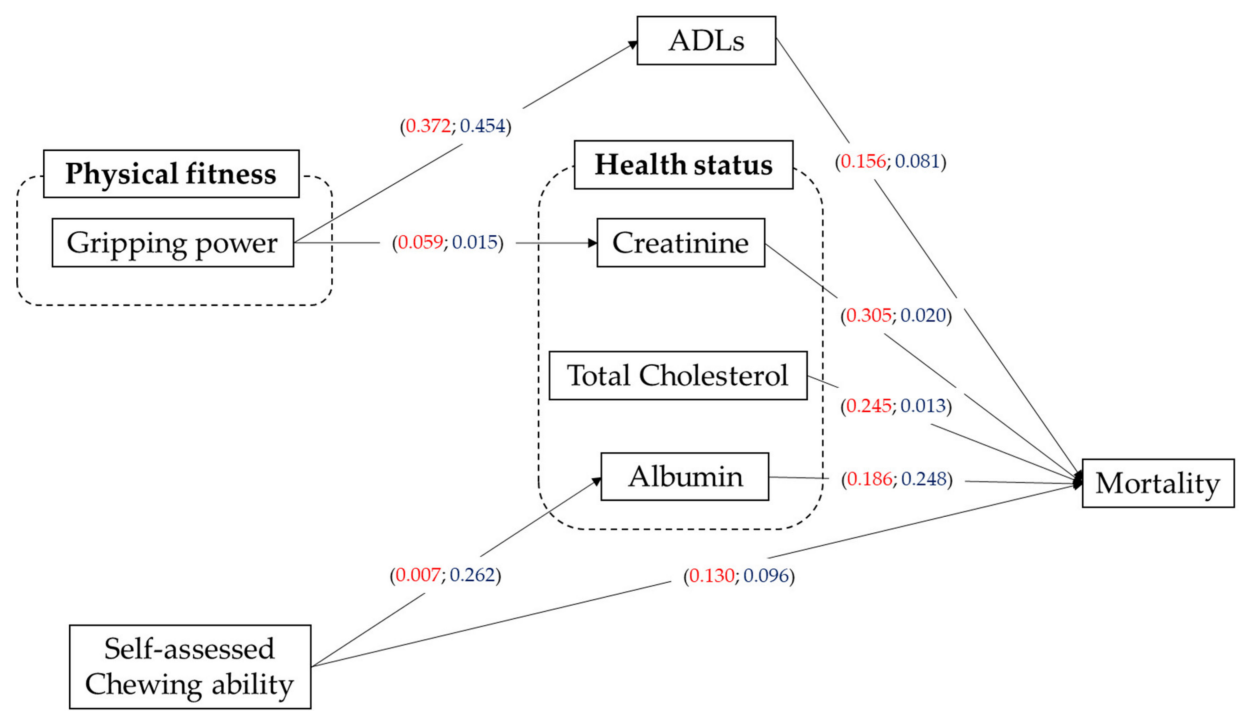

REMSEA: 0.087 (90\% CI: 0.038-0.131)

Figure 5. Overview of the effect of health-related factors on mortality for older adults at the age of 90. The correlation of health-related factors and mortality was analyzed using the path analysis. Numbers indicate the coefficients. Numbers in red are coefficients of women and in blue those of men. The fitness index was presented via REMSEA. REMSEA: root mean square error of approximation.

\section{Discussion}

In this study, we investigated health-related factors associated with the mortality of older adults at the age of 90 . Self-assessed chewing ability, ADLs, serum albumin, total cholesterol, serum creatinine, 
and grip strength were significantly associated with mortality in women but not in men. These factors interacted with each other, and the association of these factors was different in men and women.

Several studies have shown that self-assessed chewing ability or self-assessed masticatory ability was associated with dental conditions [67-69]. However, the association was weak [68]. It is also associated with general health [69,70], social factors [70], and physical performance [71]. It is a stable indicator with minor variation over time [72]. It can be the predictor or a risk factor for mortality in older adults [18-21]. In this study, self-assessed chewing ability was statistically significant for women. In addition, adjusted hazard ratios of serum albumin, total cholesterol, and creatinine were also statistically significant in women but not in men. These results indicated that self-assessed chewing ability independently effected mortality, as evaluated via blood tests. Serum albumin reflected nutritional status [73] and is a well-known predictor for mortality [74,75]. When compared with men, association between self-assessed chewing ability and serum albumin was weak in women.

A decline in physical performance is a mortality risk [39-45]. Follow-up periods, age of subjects, and predictors varied between studies: short physical performance battery [39-42], walking speed (m/s), chair stand speed [43], comfortable walking speed, timed up and go, functional reach, and one-legged, single-legged, and double-legged [44] extensor strength and isokinetic leg extensor power [45]. In this study, some tests were a burden and dangerous for the older adults. Physical performance tests could not be completely performed. Among the various physical performance tests, a decline in hand grip strength was considered a mortality risk [76-88], especially for women. Further, it was associated with ADL (Figure 4). Hand grip strength tests had little risk and were easy to perform. It may help discover the subjects with deteriorating health [89].

ADL impairment was a risk for the mortality of community-dwelling older adults [90-94]. In this study, ADLs were significantly associated with mortality in women and the "self-management" subscale, which was associated in both men and women. The "self-management" subscale contained items that required physical performances. Physical performance and ADLs interacted with each other $[95,96]$. The association between physical performance and ADLs are shown in Figure 4.

In this study, health status was evaluated via blood tests. Serum albumin, serum creatinine, and serum total cholesterol were associated with mortality in women. Serum creatine is a diagnostic marker of renal function $[97,98]$. Elevated serum creatine is a risk of mortality for patients with coronary heart disease [99-101] and is applicable for community-dwelling older adults [102-104]. Elevated total cholesterol is a risk indicator for coronary heart disease. It was also a risk for mortality [105-108]. Serum total cholesterol reflected dietary habit and nutritional status [108-113] yet was not associated with self-assessed chewing ability.

Throughout this study's results, the effects of health-related factors on mortality were different between men and women. The decline in the number of remaining teeth was a risk factor of mortality only in men [114-116]. In women [12,117], it was an insignificant risk [118]. Self-assessed chewing ability was a risk for both men and women [18-21]; see, only in men [52], and only in women [55]. Serum albumin is a risk factor for mortality both in men and women [52] and only in women [55]. In this study, self-assessed chewing ability was high risk for women and its hazard ratio was 6.7, which was measures with the optimal cut-off point. As shown in Figure 2, a clear survival curve was obtained. All women with declined self-assessed chewing ability died within 3 years of the 10-year follow-up study. Similarly, self-assessed chewing ability was a high risk for men at the age of 80 . All men with declined self-assessed chewing ability died within a short period of time. A similar result was presented for women with declined self-assessed chewing ability at the age of 85 . The life expectancy of women is longer than men. Therefore, risk factors for mortality depends on the life stage of the subjects. It may be one of the most important aspects for the contractional results between the sexes. Baseline health status, follow-up periods, and statistical models differed between studies. These factors also acted on the contractional results of sex differences.

Self-chewing ability was not associated with serum total cholesterol. Its association with serum albumin in women was very weak. When adjusted with serum albumin, the hazard ratio of self-assessed 
chewing ability was significant in women, indicating that self-assessed chewing ability independently acted on mortality. Therefore, in women, self-assessed chewing ability and nutritional status were independent. To utilize the oral function, nutritional instructions are indispensable.

The limitation of this study was that it used only a one-point health checkup to predict mortality. More precise risks can be defined by health checkups with regular intervals.

\section{Conclusions}

Self-assessed chewing ability is a strong risk factor for the mortality of women at the age of 90 , independent from nutritional status. For older adults, it is useful to address the promotion of healthy food choices together with oral function improvements. However, risk factors for mortality may depend on the life stage of subjects. To investigate risk factors for mortality, the life course approach is necessary.

Supplementary Materials: The following are available online at http://www.mdpi.com/1660-4601/17/24/9584/s1, Figure S1. Diagram of the study design; Figure S2: Survival curves for chewable dried scallops and Konnyaku jelly; Figure S3: Survival curves by subscales of ADLs; Table S1: Descriptive statistics of the variables analyzed in this study; Table S2: Three parameter logistic model for self-assessed chewing ability; Table S3: Hazard ratios of 15 types of food; Table S4: Adjusted hazard ratios of self-assessed chewing ability and ADLs by serum albumin, total cholesterol, and creatine.

Author Contributions: Y.N. planned the study design, management, and analysis of the data, and wrote the original draft. M.S. planned the study design and management and collected and managed the data. E.K., A.O., R.O., Y.T., C.T., and K.A. collected and managed the data. Y.N., H.D., T.S., and N.H. contributed to funding acquisition, planned the study design, and reviewed and edited the manuscript. All authors have read and agreed to the published version of the manuscript.

Funding: This study was supported by JSPS KAKENHI (grant numbers 17K12030, 20K10303), SECOM Science and Technology Foundation and an 8020 Research Grant for fiscal year 2017 from the 8020 Promotion Foundation (grant number 17-2-05). None of the funders played a role in the design of the study, data collection or analysis, interpretation of the results, or writing of the manuscript.

Conflicts of Interest: The authors declare no conflict of interest.

\section{References}

1. Dalwood, P.; Marshall, S.; Burrows, T.L.; McIntosh, A.; Collins, C.E. Diet quality indices and their associations with health-related outcomes in children and adolescents: An updated systematic review. Nutr. J. 2020, 19, 118. [CrossRef] [PubMed]

2. Moghaddam, L.F.; Vettore, M.V.; Bayani, A.; Bayat, A.H.; Ahounbar, E.; Hemmat, M.; Armoon, B.; Fakhri, Y. The Association of oral health status, demographic characteristics and socioeconomic determinants with oral health-related quality of life among children: A systematic review and Meta-analysis. BMC Pediatr. 2020, 20, 489. [CrossRef] [PubMed]

3. Thomas, J.M.; Cooney, L.M., Jr; Fried, T.R. Systematic review: Health-related characteristics of elderly hospitalized adults and nursing home residents associated with short-term mortality. J. Am. Geriatr. Soc. 2013, 61, 902-911. [CrossRef] [PubMed]

4. Nevill, A.M.; Holder, R.L. Modelling health-related performance indices. Ann. Hum. Biol. 2000, 27, 543-559. [CrossRef] [PubMed]

5. Gondivkar, A.M.; Gadbail, A.R.; Gondivkar, R.S.; Sarode, S.C.; Sarode, G.S.; Patil, S.; Awan, K.H. Nutrition and oral health. Dis Mon. 2019, 65, 147-154. [CrossRef] [PubMed]

6. Pla, G.W. Oral health and nutrition. Prim. Care. 1994, 21, 121-133. [PubMed]

7. Kehoe, L.; Walton, J.; Flynn, A. Nutritional challenges for older adults in Europe: Current status and future directions. Proc. Nutr. Soc. 2019, 78, 221-233. [CrossRef]

8. Hsu, Y.H.; Chou, M.Y.; Chu, C.S.; Liao, M.C.; Wang, Y.C.; Lin, Y.T.; Chen, L.K.; Liang, C.K. Predictive effect of malnutrition on long-term clinical outcomes among older men: A Prospectively Observational Cohort Study. J. Nutr. Health Aging 2019, 23, 876-882. [CrossRef] 
9. Wei, K.; Nyunt, M.S.Z.; Gao, Q.; Wee, S.L.; Ng, T.P. Long-term changes in nutritional status are associated with functional and mortality outcomes among community-living older adults. Nutrition 2019, 66, 180-186. [CrossRef]

10. Wei, K.; Nyunt, M.S.; Gao, Q.; Wee, S.L.; Yap, K.B.; Ng, T.P. Association of frailty and malnutrition with long-term functional and mortality outcomes among community-dwelling older adults: Results from the Singapore Longitudinal Aging Study 1. JAMA Netw. Open. 2018, 1, e180650. [CrossRef]

11. Verlaan, S.; Melis, L.G.C.; Wijers, S.L.J.; Cederholm, T.; Maier, A.B.; Schueren, M.A.E. High prevalence of physical frailty among community-dwelling malnourished older adults-A systematic review and meta-analysis. J. Am. Med. Dir. Assoc. 2017, 18, 374-382. [CrossRef] [PubMed]

12. Walls, A.W.; Steele, J.G.; Sheiham, A.; Marcenes, W.; Moynihan, P.J. Oral health and nutrition in older people. J. Public Health Dent. 2000, 60, 304-307. [CrossRef] [PubMed]

13. N'gom, P.I.; Woda, A. Influence of impaired mastication on nutrition. J. Prosthet Dent. 2002, 87, 667-673. [CrossRef] [PubMed]

14. Peyron, M.A.; Woda, A.; Bourdiol, P.; Hennequin, M. Age-related changes in mastication. J. Oral Rehabil. 2017, 44, 299-312. [CrossRef]

15. Nakamura, M.; Ojima, T.; Nagahata, T.; Kondo, I.; Ninomiya, T.; Yoshita, K.; Arai, Y.; Ohkubo, T.; Murakami, K.; Nishi, N.; et al. Having few remaining teeth is associated with a low nutrient intake and low serum albumin levels in middle-aged and older Japanese individuals: Findings from the NIPPON DATA2010. Environ. Health Prev. Med. 2019, 24, 1. [CrossRef]

16. Ortega, O.; Martín, A.; Clavé, P. Diagnosis and management of oropharyngeal dysphagia among older persons, state of the art. J. Am. Med. Dir. Assoc. 2017, 18, 576-582. [CrossRef]

17. Puisieux, F.; D’Andrea, C.; Baconnier, P.; Dinh, B.D.; Pelet, C.S.; Crestani, B.; Desrues, B.; Ferron, C.; Franco, A.; Gaillat, J.; et al. Swallowing disorders, pneumonia and respiratory tract infectious disease in the elderly. Rev. Mal. Respir. 2011, 28, e76-e93. [CrossRef]

18. Laudisio, A.; Gemma, A.; Fontana, D.O.; Rivera, C.; Bandinelli, S.; Ferrucci, L.; Incalzi, R.A. Self-reported masticatory dysfunction and mortality in community-dwelling elderly adults: A 9-year follow-up. J. Am. Geriatr. Soc. 2016, 64, 2503-2510. [CrossRef]

19. Nakanishi, N.; Fukuda, H.; Takatorige, T.; Tatara, K. Relationship between self-assessed masticatory disability and 9-year mortality in a cohort of community-residing elderly people. J. Am. Geriatr. Soc. 2005, 53, 54-58. [CrossRef]

20. Ansai, T.; Takata, Y.; Soh, I.; Akifusa, S.; Sogame, A.; Shimada, N.; Yoshida, A.; Hamasaki, T.; Awano, S.; Fukuhara, M.; et al. Relationship between chewing ability and 4-year mortality in a cohort of 80-year-old Japanese people. Oral Dis. 2007, 13, 214-219. [CrossRef]

21. Okura, M.; Ogita, M.; Yamamoto, M.; Nakai, T.; Numata, T.; Arai, H. Self-assessed kyphosis and chewing disorders predict disability and mortality in community-dwelling older adults. J. Am. Med. Dir. Assoc. 2017, 18, 550.e1-550.e6. [CrossRef] [PubMed]

22. Ritchie, C.S.; Joshipura, K.; Hung, H.C.; Douglass, C.W. Nutrition as a mediator in the relation between oral and systemic disease: Associations between specific measures of adult oral health and nutrition outcomes. Crit. Rev. Oral Biol. Med. 2002, 13, 291-300. [CrossRef] [PubMed]

23. Sharkey, J.R.; Branch, L.G.; Giuliani, C.; Zohoori, M.; Haines, P.S. Nutrient intake and BMI as predictors of severity of ADL disability over 1 year in homebound elders. J. Nutr. Health Aging 2004, 8, 131-139. [PubMed]

24. Pek, K.; Chew, J.; Lim, J.P.; Yew, S.; Tan, C.N.; Yeo, A.; Ding, Y.Y.; Lim, W.S. Social frailty Is independently associated with mood, nutrition, physical performance, and physical activity: Insights from a theory-guided approach. Int. J. Environ. Res. Public Health 2020, 17, 4239. [CrossRef]

25. Bramantoro, T.; Hariyani, N.; Setyowati, D.; Purwanto, B.; Zulfiana, A.A.; Irmalia, W.R. The impact of oral health on physical fitness: A systematic review. Heliyon 2020, 6, e03774. [CrossRef]

26. Saintrain, M.V.L.; Saintrain, S.V.; Sampaio, E.G.M.; Ferreira, B.S.P.; Nepomuceno, T.C.; Frota, M.A.; Meyer, V.A.P. Older adults' dependence in activities of daily living: Implications for oral health. Public Health Nurs. 2018, 35, 473-481. [CrossRef]

27. Catović, A.; Bergman, V.; Catić, A. Qualitative evaluation of elderly home residents' fixed and removable prostheses in relation to the ADL index. J. Dent. 2003, 31, 3-8. [CrossRef] 
28. Hays, J.C.; Keller, H.H.; Ostbye, T. The effects of nutrition-related factors on four-year mortality among a biracial sample of community-dwelling elders in the North Carolina piedmont. J. Nutr. Elder. 2005, 25, 41-67. [CrossRef]

29. Ricci, C.; Freisling, H.; Leitzmann, M.F.; Krugell, T.C.; Jacobs, I.; Kruger, H.S.; Smuts, C.M.; Pieters, M. Diet and sedentary behaviour in relation to cancer survival. A report from the national health and nutrition examination survey linked to the U.S. mortality registry. Clin. Nutr. 2020, 39, 3489-3496. [CrossRef]

30. DMaeda, K.; Mori, N. Poor oral health and mortality in geriatric patients admitted to an acute hospital: An observational study. BMC Geriatr. 2020, 20, 26. [CrossRef]

31. Håheim, L.L.; Nafstad, P.; Schwarze, P.E.; Olsen, I.; Rønningen, K.S.; Thelle, D.S. Oral health and cardiovascular disease risk factors and mortality of cerebral haemorrhage, cerebral infarction and unspecified stroke in elderly men: A prospective cohort study. Scand. J. Public Health 2020, 48, 762-769. [CrossRef] [PubMed]

32. Cunha, A.R.D.; Prass, T.S.; Hugo, F.N. Mortality from oral and oropharyngeal cancer in Brazil: Impact of the National Oral Health Policy. Cad. Saude Publica 2019, 35, e00014319. [CrossRef] [PubMed]

33. Jansson, L.; Kalkali, H.; Niazi, M.F. Mortality rate and oral health-A cohort study over 44 years in the county of Stockholm. Acta Odontol. Scand. 2018, 76, 299-304. [CrossRef] [PubMed]

34. Klotz, A.L.; Hassel, A.J.; Schröder, J.; Rammelsberg, P.; Zenthöfer, A. Is compromised oral health associated with a greater risk of mortality among nursing home residents? A controlled clinical study. Aging Clin. Exp. Res. 2018, 30, 581-588. [CrossRef] [PubMed]

35. Vogtmann, E.; Etemadi, A.; Kamangar, F.; Islami, F.; Roshandel, G.; Poustchi, H.; Pourshams, A.; Khoshnia, M.; Gharravi, A.; Brennan, P.J.; et al. Oral health and mortality in the Golestan Cohort Study. Int. J. Epidemiol. 2017, 46, 2028-2035. [CrossRef]

36. Adolph, M.; Darnaud, C.; Thomas, F.; Pannier, B.; Danchin, N.; Batty, G.D.; Bouchard, P. Oral health in relation to all-cause mortality: The IPC cohort study. Sci. Rep. 2017, 7, 44604. [CrossRef]

37. DJoshy, G.; Arora, M.; Korda, R.J.; Chalmers, J.; Banks, E. Is poor oral health a risk marker for incident cardiovascular disease hospitalisation and all-cause mortality? Findings from 172630 participants from the prospective 45 and Up Study. BMJ Open 2016, 6, e012386. [CrossRef]

38. DRuokonen, H.; Nylund, K.; Furuholm, J.; Meurman, J.H.; Sorsa, T.; Kotaniemi, K.; Ortiz, F.; Heikkinen, A.M. Oral health and mortality in patients with chronic kidney disease. J. Periodontol. 2017, 88, 26-33. [CrossRef]

39. Charles, A.; Detilleux, J.; Buckinx, F.; Reginster, J.Y.; Gruslin, B.; Bruyère, O. Physical performance trajectories and mortality among nursing home residents: Results of the SENIOR cohort. Age Ageing 2020, 49, 800-806. [CrossRef]

40. Mutambudzi, M.; Chen, N.W.; Howrey, B.; Garcia, M.A.; Markides, K.S. Physical performance trajectories and mortality among older Mexican Americans. J. Gerontol. A Biol. Sci. Med. Sci. 2019, 74, 233-239. [CrossRef]

41. Pavasini, R.; Guralnik, J.; Brown, J.C.; di Bari, M.; Cesari, M.; Landi, F.; Vaes, B.; Legrand, D.; Verghese, J.; Wang, C.; et al. Short physical performance battery and all-cause mortality: Systematic review and meta-analysis. BMC Med. 2016, 14, 215. [CrossRef] [PubMed]

42. Panas, L.J.; Siordia, C.; Angel, R.J.; Eschbach, K.; Markides, K.S. Physical performance and short-term mortality in very old Mexican Americans. Exp. Aging Res. 2013, 39, 481-492. [CrossRef] [PubMed]

43. Barbour, K.E.; Lui, L.Y.; McCulloch, C.E.; Ensrud, K.E.; Cawthon, P.M.; Yaffe, K.; Barnes, D.E.; Fredman, L.; Newman, A.B.; Cummings, S.R.; et al. Trajectories of lower extremity physical performance: Effects on fractures and mortality in older women. J. Gerontol. A Biol Sci. Med. Sci. 2016, 71, 1609-1615. [CrossRef] [PubMed]

44. Idland, G.; Engedal, K.; Bergland, A. Physical performance and 13.5-year mortality in elderly women. Scand. J. Public Health 2013, 41, 102-108. [CrossRef]

45. Takata, Y.; Shimada, M.; Ansai, T.; Yoshitake, Y.; Nishimuta, M.; Nakagawa, N.; Ohashi, M.; Yoshihara, A.; Miyazaki, H. Physical performance and 10-year mortality in a 70-year-old community-dwelling population. Aging Clin. Exp. Res. 2012, 24, 257-264. [CrossRef]

46. Zingmark, M.; Norström, F.; Lindholm, L.; Ivanoff, D.S.; Gustafsson, S. Modelling long-term cost-effectiveness of health promotion for community-dwelling older people. Eur. J. Ageing. 2019, 16, 395-404. [CrossRef]

47. Frost, R.; Belk, C.; Jovicic, A.; Ricciardi, F.; Kharicha, K.; Gardner, B.; Iliffe, S.; Goodman, C.; Manthorpe, J.; Drennan, V.M.; et al. Health promotion interventions for community-dwelling older people with mild or pre-frailty: A systematic review and meta-analysis. BMC Geriatr. 2017, 17, 157. [CrossRef] 
48. Kutsuna, T.; Hiyama, Y.; Kusaka, S.; Kusumoto, Y.; Tsuchiya, J.; Umeda, M.; Takahashi, T. The effect of short-term health promotion intervention on motor function in community-dwelling older adults. Aging Clin. Exp. Res. 2019, 31, 475-481. [CrossRef]

49. Neumann, L.; Dapp, U.; Kruse, R.W.; Minder, C.E. Health promotion and preventive care intervention for older community-dwelling people: Long-term effects of a Randomised Controlled Trial (RCT) within the LUCAS Cohort. J. Nutr. Health Aging 2017, 21, 1016-1023. [CrossRef]

50. Raffaele, B.; Matarese, M.; Alvaro, R.; De Marinis, D.M.G. Health-promotion theories in nutritional interventions for community-dwelling older adults: A systematic review. Ann. Ist. Super Sanita 2017, 53, 146-151. [CrossRef]

51. Nomura, Y.; Kakuta, E.; Okada, A.; Otsuka, R.; Shimada, M.; Tomizawa, Y.; Taguchi, C.; Arikawa, K.; Daikoku, H.; Sato, T.; et al. Impact of the serum level of albumin and self-assessed chewing ability on mortality, QOL, and ADLs for community-dwelling older adults at the age of 85: A 15 year follow-up study. Nutrients 2020, 12, E3315. [CrossRef] [PubMed]

52. Nomura, Y.; Kakuta, E.; Okada, A.; Otsuka, R.; Shimada, M.; Tomizawa, Y.; Taguchi, C.; Arikawa, K.; Daikoku, H.; Sato, T.; et al. Effects of self-assessed chewing ability, tooth loss and serum albumin on mortality in 80-year-old individuals: A 20-year follow-up study. BMC Oral Health 2020, 20, 122. [CrossRef] [PubMed]

53. Nomura, Y.; Kakuta, E.; Okada, A.; Otsuka, R.; Shimada, M.; Tomizawa, Y.; Taguchi, C.; Arikawa, K.; Daikoku, H.; Sato, T.; et al. Oral Microbiome in Four Female Centenarians. Appl. Sci. 2020, 10, 5312. [CrossRef]

54. Iwasaki, M.; Yoshihara, A.; Sato, M.; Minagawa, K.; Shimada, M.; Nishimuta, M.; Ansai, T.; Yoshitake, Y.; Miyazaki, H. Dentition status and frailty in community-dwelling older adults: A 5-year prospective cohort study. Geriatr. Gerontol. Int. 2018, 18, 256-262. [CrossRef]

55. Yamaga, T.; Yoshihara, A.; Ando, Y.; Yoshitake, Y.; Kimura, Y.; Shimada, M.; Nishimuta, M.; Miyazaki, H. Relationship between dental occlusion and physical fitness in an elderly population. J. Gerontol. A Biol. Sci. Med. Sci. 2002, 57, M616-M620. [CrossRef]

56. Okuyama, N.; Yamaga, T.; Yoshihara, A.; Nohno, K.; Yoshitake, Y.; Kimura, Y.; Shimada, M.; Nakagawa, N.; Nishimuta, M.; Ohashi, M.; et al. Influence of dental occlusion on physical fitness decline in a healthy Japanese elderly population. Arch. Gerontol. Geriatr. 2011, 52, 172-176. [CrossRef]

57. Koyano, W.; Shibata, H.; Nakazato, K.; Haga, H.; Suyama, Y. Measurement of competence: Reliability and validity of the TMIG Index of Competence. Arch. Gerontol. Geriatr. 1991, 13, 103-116. [CrossRef]

58. Ishizaki, T.; Kai, I.; Kobayashi, Y.; Imanaka, Y. Functional transitions and active life expectancy for older Japanese living in a community. Arch. Gerontol. Geriatr. 2002, 35, 107-120. [CrossRef]

59. Kiyoshige, E.; Kabayama, M.; Gondo, Y.; Masui, Y.; Inagaki, H.; Ogawa, M.; Nakagawa, T.; Yasumoto, S.; Akasaka, H.; Sugimoto, K.; et al. Age group differences in association between IADL decline and depressive symptoms in community-dwelling elderly. BMC Geriatr. 2019, 19, 309. [CrossRef]

60. Nomura, Y.; Otsuka, R.; Wint, W.Y.; Okada, A.; Hasegawa, R.; Hanada, N. Tooth-Level Analysis of Dental Caries in Primary Dentition in Myanmar Children. Int. J. Environ. Res. Public Health 2020, 17, 7613. [CrossRef]

61. Nomura, Y.; Kakuta, E.; Okada, A.; Yamamoto, Y.; Tomonari, H.; Hosoya, N.; Hanada, N.; Yoshida, N.; Takei, N. Prioritization of the skills to be mastered for the daily jobs of Japanese dental hygienists. Int. J. Dent. 2020, 2020, 4297646. [CrossRef] [PubMed]

62. Nomura, Y.; Matsuyama, T.; Fukai, K.; Okada, A.; Ida, M.; Yamauchi, N.; Hanamura, H.; Yabuki, Y.; Watanabe, K.; Sugawara, M.; et al. PRECEDE-PROCEED model based questionnaire and saliva tests for oral health checkup in adult. J. Oral. Sci. 2019, 61, 544-548. [CrossRef] [PubMed]

63. Nomura, Y.; Maung, K.; Khine, K.E.M.; Sint, K.M.; Lin, M.P.; Myint, W.M.K.; Aung, T.; Sogabe, K.; Otsuka, R.; Okada, A.; et al. Prevalence of dental caries in 5- and 6-year-old Myanmar children. Int. J. Dent. 2019, 2019, 5948379. [CrossRef] [PubMed]

64. Nomura, Y.; Tsutsumi, I.; Nagasaki, M.; Tsuda, H.; Koga, F.; Kashima, N.; Uraguchi, M.; Okada, A.; Kakuta, E.; Hanada, N. Supplied Food Consistency and Oral Functions of Institutionalized Elderly. Int. J. Dent. 2020, 2020, 3463056. [CrossRef] [PubMed]

65. Nomura, Y.; Ishii, Y.; Suzuki, S.; Morita, K.; Suzuki, A.; Suzuki, S.; Tanabe, J.; Ishiwata, Y.; Yamakawa, K.; Chiba, Y.; et al. Nutritional status and oral frailty: A community based study. Nutrients 2020, 12, E2886. [CrossRef] 
66. Nomura, Y.; Okada, A.; Miyoshi, J.; Mukaida, M.; Akasaka, E.; Saigo, K.; Daikoku, H.; Maekawa, H.; Sato, T.; Hanada, N. Willingness to Work and the Working Environment of Japanese Dental Hygienists. Int. J. Dent. 2018, 2018, 2727193. [CrossRef]

67. Moriya, S.; Tei, K.; Muramatsu, T.; Murata, A.; Muramatsu, M.; Harada, E.; Inoue, N.; Miura, H. Factors associated with self-assessed masticatory ability among community-dwelling elderly Japanese. Community Dent. Health 2012, 29, 39-44.

68. Tsuga, K.; Carlsson, G.E.; Osterberg, T.; Karlsson, S. Self-assessed masticatory ability in relation to maximal bite force and dental state in 80-year-old subjects. J. Oral Rehabil. 1998, 25, 117-124. [CrossRef]

69. Unell, L.; Johansson, A.; Ekbäck, G.; Ordell, S.; Carlsson, G.E. Dental status and self-assessed chewing ability in 70- and 80-year-old subjects in Sweden. J. Oral Rehabil. 2015, 42, 693-700. [CrossRef]

70. Nakanishi, N.; Hino, Y.; Ida, O.; Fukuda, H.; Shinsho, F.; Tatara, K. Associations between self-assessed masticatory disability and health of community-residing elderly people. Community Dent. Oral Epidemiol. 1999, 27, 366-371. [CrossRef]

71. Moriya, S.; Notani, K.; Miura, H.; Inoue, N. Relationship between masticatory ability and physical performance in community-dwelling edentulous older adults wearing complete dentures. Gerodontology 2014, 31, 251-259. [CrossRef] [PubMed]

72. Osterberg, T.; Carlsson, G.E. Dental state, prosthodontic treatment and chewing ability-A study of five cohorts of 70-year-old subjects. J. Oral Rehabil. 2007, 34, 553-559. [CrossRef] [PubMed]

73. Don, B.R.; Kaysen, G. Serum albumin: Relationship to inflammation and nutrition. Semin. Dial. 2004, 17, 432-437. [CrossRef] [PubMed]

74. Goldwasser, P.; Feldman, J. Association of serum albumin and mortality risk. J. Clin. Epidemiol. 1997, 50, 693-703. [CrossRef]

75. Takata, Y.; Ansai, T.; Yoshihara, A.; Miyazaki, H. Serum albumin (SA) levels and 10-year mortality in a community-dwelling 70-year-old population. Arch. Gerontol. Geriatr. 2012, 54, 39-43. [CrossRef]

76. Soares, V.N.; Fattori, A.; Neri, A.L.; Fernandes, P.T. Influence of physical performance on elderly mortality, functionality and life satisfaction: FIBRA's study data. Cien Saude Colet. 2019, 24, 4181-4190. [CrossRef]

77. Veronese, N.; Stubbs, B.; Fontana, L.; Trevisan, C.; Bolzetta, F.; Rui, M.; Sartori, L.; Musacchio, E.; Zambon, S.; Maggi, S.; et al. A Comparison of objective physical performance tests and future mortality in the elderly people. J. Gerontol. A Biol. Sci. Med. Sci. 2017, 72, 362-368. [CrossRef]

78. Landi, F.; Russo, A.; Liperoti, R.; Pahor, M.; Tosato, M.; Capoluongo, E.; Bernabei, R.; Onder, G. Midarm muscle circumference, physical performance and mortality: Results from the aging and longevity study in the Sirente geographic area (ilSIRENTE study). Clin. Nutr. 2010, 29, 441-447. [CrossRef]

79. Rolland, Y.; Cances, L.V.; Cesari, M.; Vellas, B.; Pahor, M.; Grandjean, H. Physical performance measures as predictors of mortality in a cohort of community-dwelling older French women. Eur. J. Epidemiol. 2006, 21, 113-122. [CrossRef]

80. Nofuji, Y.; Shinkai, S.; Taniguchi, Y.; Amano, H.; Nishi, M.; Murayama, H.; Fujiwara, Y.; Suzuki, T. Associations of walking speed, grip strength, and standing balance with total and cause-specific mortality in a General Population of Japanese Elders. J. Am. Med. Dir. Assoc. 2016, 17, e1-e7. [CrossRef]

81. May, O.; Arildsen, H. Simple function tests for autonomic neuropathy have a higher predictive value on all-cause mortality in diabetes compared to 24-h heart rate variability. J. Diabetes Complicat. 2012, 26, 246-250. [CrossRef] [PubMed]

82. McDermott, M.M.; Liu, K.; Tian, L.; Guralnik, J.M.; Criqui, M.H.; Liao, Y.; Ferrucci, L. Calf muscle characteristics, strength measures, and mortality in peripheral arterial disease: A longitudinal study. J. Am. Coll Cardiol. 2012, 59, 1159-1167. [CrossRef] [PubMed]

83. Rantanen, T.; Volpato, S.; Ferrucci, L.; Heikkinen, E.; Fried, L.P.; Guralnik, J.M. Handgrip strength and cause-specific and total mortality in older disabled women: Exploring the mechanism. J. Am. Geriatr. Soc. 2003, 51, 636-641. [CrossRef] [PubMed]

84. Kishimoto, H.; Hata, J.; Ninomiya, T.; Nemeth, H.; Hirakawa, Y.; Yoshida, D.; Kumagai, S.; Kitazono, T.; Kiyohara, Y. Midlife and late-life handgrip strength and risk of cause-specific death in a general Japanese population: The Hisayama Study. J. Epidemiol. Community Health 2014, 68, 663-668. [CrossRef] [PubMed]

85. Kim, G.R.; Sun, J.; Han, M.; Park, S.; Nam, C.M. Impact of handgrip strength on cardiovascular, cancer and all-cause mortality in the Korean longitudinal study of ageing. BMJ Open. 2019, 9, e027019. [CrossRef] 
86. Hatabe, Y.; Shibata, M.; Ohara, T.; Oishi, E.; Yoshida, D.; Honda, T.; Hata, J.; Kanba, S.; Kitazono, T.; Ninomiya, T. Decline in handgrip strength from midlife to late-life is associated with dementia in a Japanese community: The Hisayama Study. J. Epidemiol. 2020, 30, 15-23. [CrossRef]

87. Sasaki, H.; Kasagi, F.; Yamada, M.; Fujita, S. Grip strength predicts cause-specific mortality in middle-aged and elderly persons. Am. J. Med. 2007, 120, 337-342. [CrossRef]

88. Ling, C.H.; Taekema, D.; de Craen, A.J.; Gussekloo, J.; Westendorp, R.G.; Maier, A.B. Handgrip strength and mortality in the oldest-old population: The Leiden 85-plus study. CMAJ 2010, 182, 429-435. [CrossRef]

89. Sugiura, Y.; Tanimoto, Y.; Watanabe, M.; Tsuda, Y.; Kimura, M.; Kusabiraki, T.; Kono, K. Handgrip strength as a predictor of higher-level competence decline among community-dwelling Japanese elderly in an urban area during a 4-year follow-up. Arch. Gerontol. Geriatr. 2013, 57, 319-324. [CrossRef]

90. Calenti, M.J.C.; Tubío, J.; Fernández, P.S.; Abraldes, G.I.; Lorenzo, T.; Arruty, F.T.; Maseda, A. Prevalence of functional disability in activities of daily living (ADL), instrumental activities of daily living (IADL) and associated factors, as predictors of morbidity and mortality. Arch. Gerontol. Geriatr. 2010, 50, 306-310. [CrossRef]

91. Oida, Y.; Kitabatake, Y.; Nishijima, Y.; Nagamatsu, T.; Kohno, H.; Egawa, K.; Arao, T. Effects of a 5-year exercise-centered health-promoting programme on mortality and ADL impairment in the elderly. Age Ageing 2003, 32, 585-592. [CrossRef] [PubMed]

92. Liao, C.C.; Li, C.R.; Lee, S.H.; Liao, W.C.; Liao, M.Y.; Lin, J.; Yeh, C.J.; Lee, M.C. Social support and mortality among the aged people with major diseases or ADL disabilities in Taiwan: A national study. Arch. Gerontol. Geriatr. 2015, 60, 317-321. [CrossRef] [PubMed]

93. Gobbens, R.J.J.; van der Ploeg, T. The prediction of mortality by disability among Dutch community-dwelling older people. Clin. Interv. Aging. 2020, 15, 1897-1906. [CrossRef] [PubMed]

94. Tomioka, K.; Kurumatani, N.; Hosoi, H. Relationship of having hobbies and a purpose in life with mortality, activities of daily living, and instrumental activities of daily living among community-dwelling elderly adults. J. Epidemiol. 2016, 26, 361-370. [CrossRef] [PubMed]

95. Idland, G.; Pettersen, R.; Avlund, K.; Bergland, A. Physical performance as long-term predictor of onset of activities of daily living (ADL) disability: A 9-year longitudinal study among community-dwelling older women. Arch. Gerontol. Geriatr. 2013, 56, 501-506. [CrossRef]

96. Kempen, G.I.; Ormel, J. The impact of physical performance and cognitive status on subsequent ADL disability in low-functioning older adults. Int. J. Geriatr. Psychiatry 1998, 13, 480-483. [CrossRef]

97. Koch, A.J.; Pereira, R.; Machado, M. The creatine kinase response to resistance exercise. J. Musculoskelet. Neuronal. Interact. 2014, 14, 68-77.

98. Brancaccio, P.; Maffulli, N.; Buonauro, R.; Limongelli, F.M. Serum enzyme monitoring in sports medicine. Clin. Sports Med. 2008, 27,1-18. [CrossRef]

99. Tricoci, P.; Leonardi, S.; White, J.; White, H.D.; Armstrong, P.W.; Montalescot, G.; Giugliano, R.P.; Gibson, C.M.; Werf, V.F.; Califf, R.M.; et al. Cardiac troponin after percutaneous coronary intervention and 1-year mortality in non-ST-segment elevation acute coronary syndrome using systematic evaluation of biomarker trends. J. Am. Coll. Cardiol. 2013, 62, 242-251. [CrossRef]

100. Petäjä, L.; Salmenperä, M.; Pulkki, K.; Pettilä, V. Biochemical injury markers and mortality after coronary artery bypass grafting: A systematic review. Ann. Thorac. Surg. 2009, 87, 1981-1992. [CrossRef]

101. Harrington, R.A. Cardiac enzyme elevations after percutaneous coronary intervention: Myonecrosis, the coronary microcirculation and mortality. J. Am. Coll. Cardiol. 2000, 35, 1142-1144. [CrossRef]

102. Maaravi, Y.; Bursztyn, M.; Rozenberg, H.R.; Cohen, A.; Stessman, J. Moderate renal insufficiency at 70 years predicts mortality. QJM 2006, 99, 97-102. [CrossRef] [PubMed]

103. Strandberg, T.E.; Pitkala, K.H.; Tilvis, R.S. Predictors of mortality in home-dwelling patients with cardiovascular disease aged 75 and older. J. Am. Geriatr. Soc. 2009, 57, 279-284. [CrossRef] [PubMed]

104. Bates, C.J.; Hamer, M.; Mishra, G.D. A study of relationships between bone-related vitamins and minerals, related risk markers, and subsequent mortality in older British people: The National Diet and Nutrition Survey of People Aged 65 Years and Over. Osteoporos Int. 2012, 23, 457-466. [CrossRef] [PubMed]

105. Kwon, D.; Yi, J.J.; Ohrr, H.; Yi, S.W. Total cholesterol and mortality from ischemic heart disease and overall cardiovascular disease in Korean adults. Medicine 2019, 98, e17013. [CrossRef] [PubMed] 
106. Zhu, Y.; Lu, J.M.; Yu, Z.B.; Li, D.; Wu, M.Y.; Shen, P.; Lin, H.B.; Wang, J.B.; Chen, K. Intra-individual variability of total cholesterol is associated with cardiovascular disease mortality: A cohort study. Nutr. Metab. Cardiovasc. Dis. 2019, 29, 1205-1213. [CrossRef]

107. Jeong, S.M.; Choi, S.; Kim, K.; Kim, S.M.; Lee, G.; Son, J.S.; Yun, J.M.; Park, S.M. Correction: Association of change in total cholesterol level with mortality: A population-based study. PLoS ONE. 2019, 14, e0215934. [CrossRef]

108. Yi, S.W.; Yi, J.J.; Ohrr, H. Total cholesterol and all-cause mortality by sex and age: A prospective cohort study among 12.8 million adults. Sci. Rep. 2019, 9, 1596. [CrossRef]

109. Kondo, I.; Funahashi, K.; Nakamura, M.; Ojima, T.; Yoshita, K.; Nakamura, Y.; NIPPON DATA $80 / 90$ Research Group. Association between food group intake and serum total cholesterol in the Japanese population: NIPPON DATA 80/90. J. Epidemiol. 2010, 20, S576-S581. [CrossRef]

110. Ernst, N.D.; Sempos, C.T.; Briefel, R.R.; Clark, M.B. Consistency between US dietary fat intake and serum total cholesterol concentrations: The National Health and Nutrition Examination Surveys. Am. J. Clin. Nutr. 1997, 66, 965S-972S. [CrossRef]

111. Fehily, A.M.; Milbank, J.E.; Yarnell, J.W.; Hayes, T.M.; Kubiki, A.J.; Eastham, R.D. Dietary determinants of lipoproteins, total cholesterol, viscosity, fibrinogen, and blood pressure. Am. J. Clin. Nutr. 1982, 36, 890-896. [CrossRef] [PubMed]

112. Ueshima, H.; Iida, M.; Shimamoto, T.; Konishi, M.; Tanigaki, M.; Doi, M.; Nakanishi, N.; Takayama, Y.; Ozawa, H.; Komachi, Y. Dietary intake and serum total cholesterol level: Their relationship to different lifestyles in several Japanese populations. Circulation 1982, 66, 519-526. [CrossRef] [PubMed]

113. Booth, S.; Lacey, R.W. Effect of recent food on estimation of high-density lipoprotein and total cholesterol in normal subjects. Ann. Clin. Biochem. 1982, 19, 176-181. [CrossRef]

114. Morita, I.; Nakagaki, H.; Kato, K.; Murakami, T.; Tsuboi, S.; Hayashizaki, J.; Toyama, A.; Hashimoto, M.; Simozato, T.; Morishita, N.; et al. Relationship between survival rates and numbers of natural teeth in an elderly Japanese population. Gerodontology 2006, 23, 214-218. [CrossRef] [PubMed]

115. Hämäläinen, P.; Meurman, J.H.; Keskinen, M.; Heikkinen, E. Relationship between dental health and 10-year mortality in a cohort of community-dwelling elderly people. Eur. J. Oral. Sci. 2003, 111, 291-296. [CrossRef] [PubMed]

116. Osterberg, T.; Carlsson, G.E.; Sundh, V.; Mellström, D. Number of teeth-a predictor of mortality in 70-year-old subjects. Community Dent. Oral. Epidemiol. 2008, 36, 258-268. [CrossRef] [PubMed]

117. Osterberg, T.; Carlsson, G.E.; Sundh, V.; Steen, B. Number of teeth-A predictor of mortality in the elderly? A population study in three Nordic localities. Acta Odontol. Scand. 2007, 65, 335-340. [CrossRef]

118. Hirotomi, T.; Yoshihara, A.; Ogawa, H.; Miyazaki, H. Number of teeth and 5-year mortality in an elderly population. Community Dent. Oral Epidemiol. 2015, 43, 226-231. [CrossRef]

Publisher's Note: MDPI stays neutral with regard to jurisdictional claims in published maps and institutional affiliations.

(C) 2020 by the authors. Licensee MDPI, Basel, Switzerland. This article is an open access article distributed under the terms and conditions of the Creative Commons Attribution (CC BY) license (http://creativecommons.org/licenses/by/4.0/). 